\title{
Observations on Urinary White Cell Excretion Before and After Surgery
}

\author{
R. M. LINDSAY,* M.B.; B. LUNAN, $\dagger$ M.B. ; J. MCGEACHIE, $\ddagger$ M.D., M.C.PATH. \\ A. L. LINTON,§ M.B., M.R.C.P.ED., M.R.C.P.GLASG.
}

Brit. med. F., 1967, 3, 83-85

Quantitative determination of the cells excreted in the urine has until recently been regarded as a cumbersome and time(1957) attempted to simplify the teclmique, and McGeachie and Kennedy (1963) described a method of semi-quantitative cell counting which was suitable for routine use yet was much more accurate than the ordinary wet-film technique. In the course of a recent study of renal function after surgery (Lindsay et al., 1965) it was observed that there was a considerable difference between urinary white cell excretion rates before and after surgery in many patients, so further investigation of this was undertaken.

\section{Patients and Methods}

A group of 138 patients ( 81 males and 57 females) undergoing surgery in a general surgical ward were studied. The surgical procedures ranged from ligation of varicose veins to total colectomy, and any patient having direct interference with the genitourinary tract (including catheterization) was excluded. All had general anaesthesia. Preoperatively each patient was questioned about urinary tract symptoms, and any definite history of urinary tract infection or catheterization was recorded. Semi-quantitative cell counts, as described by McGeachie and Kennedy (1963), were performed on clean midconsuming procedure (Lancet, 1961). Houghton and Pears

than $600 \mathrm{ml}$. of urine between 24 and 48 hours after operation were excluded.

In 62 consecutive patients in the group urine was sent for bacteriological examination before and after operation. Delays in transmission of specimens to the laboratory were minimized, and bacterial counting was done by the method described by McGeachie and Kennedy (1963).

In a further group of 14 patients (4 males and 10 females) fully quantitative cell counts were done before and after operation. These were carried out on accurate three-hour urine collections kept acid to litmus and refrigerated during the collection. The cells were counted by the method of Houghton and Pears (1957) after staining by Prescott and Brodie's method (1964). Bacterial counts were performed concurrently on all of these specimens.

A further group of 46 patients (23 males and 23 females) aged 9 to 80 years undergoing minor surgery on the ear, nose, or throat were studied in addition to the 152 general surgical patients.

\section{Results}

The staining technique of Prescott allows the counting of white blood cells, red blood cells, tubular cells, and squamous epithelial cells. A considerable difference was found between rates of excretion preoperatively and postoperatively only for white cells; no further reference will be made to the other types of cell counted.

In the general surgical group, of the 81 males only $5(6 \%)$ had a urinary white cell count above the normal range preoperatively, and $9(11 \%)$ had an abnormal cell count postoperatively, including all the five originally abnormal. Of the 57 females of this group $6(10.5 \%)$ showed an abnormal cell count preoperatively, but $35(61 \%)$ were abnormal postoperatively.

As shown in the Table, seven of the nine males with an increased white cell excretion postoperatively gave a history of urinary tract infection or of catheterization. The relation of history of urinary infection or catheterization in the females is also shown in the Table. The age distribution of all patients with an abnormal postoperative white cell count is given in Figs. 1 and 2. patients. No bacterial count of more than 100,000 organisms within two hours of collection. In all cases the urinary cells were stained by the method of Prescott and Brodie (1964) to differentiate between white cells and tubular cells. Each patient was seen again 24 to 48 hours after operation; urinary symptoms were recorded and the cell count was repeated. Urine volumes were recorded, and patients who excreted less

\footnotetext{
- Senior House Officer in Medicine, Royal Infirmary, Glasgow C.4 + Senior House Officer in Surgery, Royal Infirmary, Glasgow C.4. Senior Lecturer in Bacteriology, Royal Infirmary, Glasgow C.4. Consultant Physician in Renal Diseases, Western Infirmary, Glasgow $\mathbf{W} .1$.
}

Correlation Between Past History and an Increased Urinary White Cell Excretion Postoperatively in 81 Males

\begin{tabular}{|c|c|c|c|c|c|c|}
\hline \multirow{3}{*}{$\begin{array}{c}\text { Past } \\
\text { History }\end{array}$} & \multicolumn{3}{|c|}{ Males } & \multicolumn{3}{|c|}{ Females } \\
\hline & \multirow{2}{*}{ No. } & \multicolumn{2}{|c|}{ Cell Count } & \multirow{2}{*}{ No. } & \multicolumn{2}{|c|}{ Cell Count } \\
\hline & & Negative & Positive & & Negative & Positive \\
\hline \pm & $\begin{array}{r}8 \\
73\end{array}$ & 71 & $\begin{array}{l}7 \\
2\end{array}$ & $\begin{array}{r}8 \\
49\end{array}$ & 20 & $\begin{array}{r}6 \\
29\end{array}$ \\
\hline
\end{tabular}


per $\mathrm{ml}$. was obtained preoperatively and only one postoperatively. This was associated with an abnormal cell count. In the 38 male patients who were negative bacteriologically two abnormal cell counts were obtained postoperatively, associated with negative cultures. Both patients had been given antibiotics since the day of operation.

Of the 23 consecutive female patients in whom bacterial counts were done four had above 100,000 organisms per ml. preoperatively and five postoperatively (the latter five includes the previous four), all of the positive postoperative counts being associated with abnormal urinary white cell excretion. A further five patients had increased white cell excretion postoperatively, but negative culture; three of these five had been receiving antibiotics since operation.

In the 14 patients in whom fully quantitative cell counts were done the upper limit for normal white cell excretion rate was chosen as 400,000 cells per hour ; this is higher than most authors suggest (Addis, 1926; Rofe, 1955; Houghton and Pears, 1957 ; Hutt et al., 1961). Of the 10 female patients so examined only one had an abnormal cell excretion rate preoperatively, and this was associated with a bacterial count in excess of 100,000 organisms per ml. (Fig. 3). Postoperatively

quantitative cell counts, and bacterial counting suggested that in most cases it was accompanied by significant bacteriuria $(>100,000$ organisms per $\mathrm{ml}$.). There did not appear to be any relation between type of surgery or duration of anaesthesia and the increased white cell excretion. Almost all of the male patients who showed increased white cell excretion postoperatively had a history of previous urinary tract infection or of catheterization; this relation was less definite in the females.

With unexpected findings of this nature the accuracy of the techniques used must always be questioned. The increased white cell excretion was detected by the semi-quantitative technique of McGeachie and Kennedy (1963), which does not take into account the volume of urine passed. It is obviously possible that oliguria might give false-positive results, but all oliguric patients were excluded from the study. Almost all of the patients studied passed more than 1 litre of urine between 24 and 48 hours after operation, and at this urine volume the upper limit of normal for the McGeachie and Kennedy method corresponds to a urinary excretion of 350,000 white cells per hour; the authors themselves established that the method gives few false-positive results. Fully quantitative cell counts confirmed the findings, 400,000 white cells excreted per hour being taken as the upper limit of normal, as is generally accepted (Hutt et al., 1961 ; Kennedy et al., 1964). The use of the differential staining techniques described by Prescott and Brodie (1964) ensured that the cells counted were white cells and not the otherwise indistinguishable small renal tubular cells.

Prescott (1966) suggested that the normal urinary white cell excretion rate for males is much lower than for females, and it might be that this would explain the sex difference noted in the present study. However, almost none of the males showed any rise at all in white cell excretion rates, while the vast majority of females who are recorded as showing positive cell counts were very clearly above the upper limit of normal even for females. The fact that we have observed this marked sex difference would militate against another possible explanation of postoperative rise in white cell excretion, the use of analgesics, which may increase urinary cell Fig. 3.- White cell excretion rates and bacterial counts in 10 females undergoing general going general surgery.

there were five cases with abnormal white cell excretion, four of which were associated with positive bacterial counts. Of the four male patients in whom fully quantitative cell counts were done none showed increased white cell excretion either before or after operation (Fig. 4).

In the additional group of 46 patients who were studied while undergoing minor surgery of the ear, nose, or throat, none of the 23 males had positive cell counts or bacterial counts at any time. Of the 23 females four showed an abnormal rise in urinary white cell excretion after surgery, and three of them gave a past history of urinary tract infection.

In the whole group of 198 patients only four females complained of urinary symptoms postoperatively, and in each case this was associated with increased white cell excretion. There was no evidence that type of surgery or duration of anaesthesia had any influence on the numbers of patients showing increased white cell excretion or significant bacteriuria.

\section{Discussion}

This study has shown that in many patients undergoing surgery unrelated to the genitourinary system there is a marked rise in urinary white cell excretion postoperatively. Furthermore, this phenomenon was noted in $61 \%$ of the females studied, but in only $11 \%$ of the males. The rise in the females is highly significant $(P<0.001)$. The increased white cell excretion rate was confirmed in a small number of cases by fully. excretion. In addition, Prescott (1965) showed that the increased cell count after analgesic ingestion was due to a rise in renal tubular cell excretion, not leucocytes. Finally, bacterial counting strongly suggests that the cases in this series which showed a rise in white cell excretion very often had significant bacteriuria also.

Houghton and Pears (1957) studied variations in the rate of leucocyte excretion in the urine of normal subjects ; they found no differences with age or sex, and only slight differences with posture and time of collection. On the other hand, Prescott (1966) showed a marked sex difference, considerable variation from patient to patient, and even from time to time in the same patient. It must be remembered, however, that these differences were all within the normal range. Other documented reasons for increases in urinary leucocyte excretion to above the normal range are urinary tract infections, during fever in pneumonia (Goldring, 1931), in pregnancy (Elden and Cooney, 1935), and after vigorous exercise (Roberts, 1935). None of these situations was applicable to the present study.

The cause of the abnormalities recorded in this paper remains uncertain. The marked sex difference, the fact that males showing a rise in white cell excretion postoperatively almost all had a previous history of urinary tract infection, and the association of pyuria and significant bacteriuria all suggest that the phenomenon is related in some way to urinary tract infection. It might be suggested that pooling of urine in the bladder postoperatively contributed to the significant bacteriuria or even to the pyuria, but the collections were not made on the first 
postoperative day, and it is unlikely that this would explain the marked sex difference. It is highly unlikely that over $60 \%$ of apparently normal women had latent urinary tract infection, but perhaps the changes we have observed are in some way related to the unknown cause underlying the increased susceptibility of the female to urinary tract infection.

\section{Summary}

Semi-quantitative urinary white cell counts were performed in 198 patients before and after surgery. A significant rise in white cell excretion rates was found in $61 \%$ of the females but in only $11 \%$ of the males. The results were confirmed in a further group of patients by means of fully quantitative cell counts, and bacterial counting showed that this pyuria was often associated with significant bacteriuria. The possible significance of these findings is discussed.

\section{REFERENCES}

Addis, T. (1926). 7. clin. Invest., 2, 409.

Elden, C. A., and Cooney, J. W. (1935). Ibid., 14, 889.

Goldring, W. (1931). Ibid., 10, 355.

Houghton, B. J., and Pears, M. A. (1957). Brit. med. F., 1, 622. Hutt, M. S. R., Chalmers, J. A., MacDonald, J. S., and de Wardener,

Kennedy, W. P. U., Ormonde, N. W. H., and Murdoch, J. McC. (1964). Brit. 7. Urol., 36, 354.

Lancet, 1961, 2, 1077.

Lindsay, R. M., Linton, A. L., and Longland, C. J. (1965). Lancet, 1,978 .

McGeachie, J., and Kennedy, A. C. (1963). F. clin. Path., 16, 32. Prescott, L. F. (1965). Lancet, 2, 91.

- (1966). Clin. Sci., 31, 425.

and Brodie, D. E. (1964). Lancet, 2, 940.

Roberts, A. M. (1935). ‡. clin. Invest., 14, 31.

Rofe, P. (1955). F. clin. Path., 8, 25.

\title{
Use of Diazepam in Treatment of Severe Convulsive Status Epilepticus
}

\author{
MAURICE J. PARSONAGE,* M.B., B.SC., F.R.C.P., D.C.H. ; JOHN W. NORRIS, † M.B., M.R.C.P.
}

Brit. med. F., 1967, 3, 85-88

During the past three years diazepam (Valium) has been used extensively, both in Europe and in the U.S.A., chiefly as a tranquillizing agent but also as an anticonvulsant (Gross and Kaltenbäck, 1963 ; Goldstein, 1963 ; Trolle, 1965). Until recently there have been comparatively few published accounts of its use in the treatment of status epilepticus. One of the earliest was that of Naquet et al. (1965), and others were by Gastaut et al. (1965), Iborra (1965), Piqué and Henking (1965), Revol et al. (1965), Bamberger and Matthes (1966), and Lombroso (1966).

In common with chlordiazepoxide (Librium) and nitrazepam (Mogadon), diazepam is a member of the benzodiazepine group of drugs. It has tranquillizing, muscle relaxant, and anticonvulsant actions. In experimental animals its depressant action has been found to act mainly on structures in the limbic system, including the hippocampus, amygdala, and reticular formation (Randall et al., 1961 ; Morillo, 1962 ; Hernández-Peón et al., 1964 ; Schallek et al., 1964 ; Schallek and Kuehn, 1965). It has also been shown that seizures arising in the amygdala in rats can be prevented by the prior administration of this drug (Eidelberg et al., 1965). The literature relative to this subject has been extensively reviewed by Boyer (1966).

- Consultant Neurologist, General Infirmary at Leeds, Leeds 1.

t Registrar, Neurological Department, General Infirmary at Leeds, Leeds 1 .
We report here the use of diazepam in the treatment of nine severe cases of convulsive status epilepticus.

\section{Material and Methods}

There were four males and five females, whose ages ranged from 11 to 53 years (Table I). In practically all cases the epilepsy was of long standing and probably associated with gross brain damage. In at least six of the nine patients there was a probable source of seizure discharge in one or other frontal lobe, and in several instances there had been previous episodes of convulsive status epilepticus.

After admission to hospital all patients were at first given diazepam in 10-mg. doses ( 1 ampoule), either intravenously or intramuscularly as required. When it became apparent that the drug had only a transient action it was given as an intravenous infusion, initially in a dosage of $100 \mathrm{mg}$. in 1 litre of physiological saline. Latterly, intravenous infusions of $100 \mathrm{mg}$. of the drug in $500 \mathrm{ml}$. of saline were given.

All patients had the usual nursing care, with particular attention to respiratory function and to fluid and electrolyte balance. Whenever it was thought necessary tracheostomy and controlled respiration were employed. Tests for liver function were carried out in Cases 5-9. In most of the patients E.E.G. studies had previously been carried out with resulting location

TABLE I

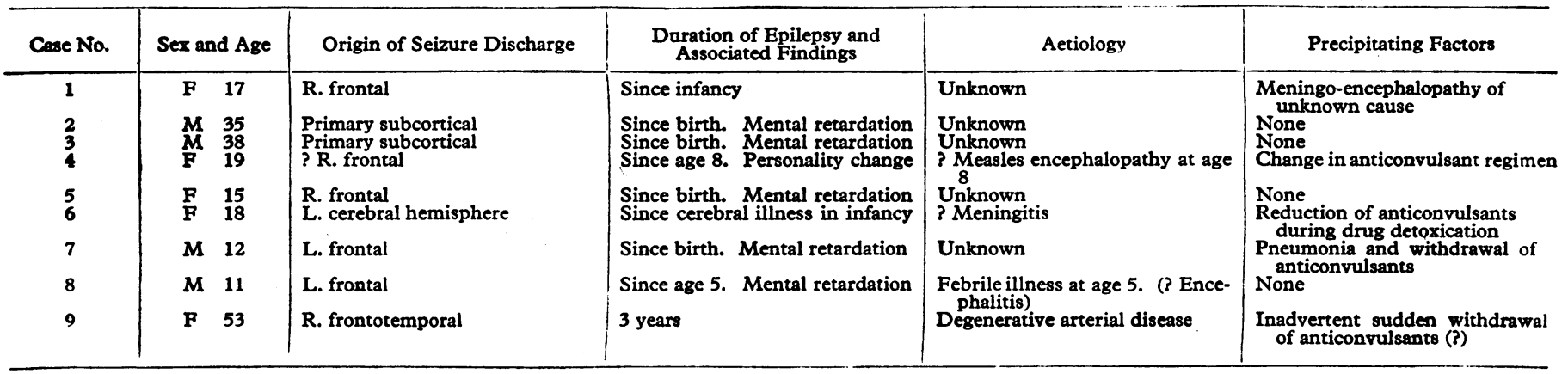

